\title{
David Dale Owen and the First Geological Survey
}

\author{
BY WALTER B. HendRICKSON
}

On September 17, 1839, a steamboat landed at the little town of Rockingham, Iowa, and its passengers disembarked. They were the personnel of the most spectacular of the many geological surveys and explorations carried out by the United States government in the Western lands. The leader of these more than one hundred men who made camp on the bank of the Mississippi River that September day was Doctor David Dale Owen, a young physician, geologist, and scientist.

Owen, Scotch-Welsh in ancestry, had lived his youthful years in Scotland and Switzerland. The third son of the great British socialist and philanthropist, Robert Owen, he had enjoyed an excellent European scientific education. $^{1}$ When Dale was twenty-one years old, hoping to become an industrial chemist, he came to America to join his father in New Harmony, Indiana. This little town on the Wabash River was the site chosen by Robert Owen for inaugurating an experiment in communal living. He planned to have a self-supporting agricultural and industrial community. But Robert Owen was a dreamer and not a doer. Young Dale Owen found himself without employment when the community failed in 1828 and the members left to seek greater economic advantages in the booming West. After a period of indecision about his life's work, Owen finally returned to his first love, science, and after a year at London University and two years at the Medical College of Ohio, he secured an appointment as the first state geologist of Indiana in $1837 .{ }^{2}$

Doctor Owen was thus one of the pioneers in the investigation of the natural resources of the Middle West, and

${ }^{1}$ David Dale Owen was born in New Lanark. Scotland, on June 23, 1807, His mother was Caroline Dale, the daughter of David Dale, a Scotch cotton mill owner.

"See Walter B. Hendrickson, "David Dale Owen, Pioneer Geologist of the Middle West," Ph. D. Thesis (Ms), 1941, in Harvard College Library ; also Walter B. Hendrickson, "David Dale Owen and Indiana's First Geological Survey," Indiana. Magazine of History, XXXVI (1940), 1-15. 
he made a thoroughly competent and even brilliant exposition of the minerals and soils of his native state. On the strength of his good work, and probably through the influence of his brother, Robert Dale Owen, a leader in the Indiana Democratic party, the young geologist was appointed "Principal Agent to Explore the Mineral Lands of the United States" on July 31, 1839, by James Whitcomb, also of Indiana, then Commissioner of the United States Land Office. ${ }^{3}$

Back of this appointment was a long story concerning the administration of the public lands of the United States. It began in 1785 with the Land Ordinance for the Old Northwest Territory, passed by the Congress of the Confederation. In addition to the marvelously efficient system of rectangular survey by which the public domain was divided into congressional townships and sections, the Land Ordinance of 1785 contained other important clauses, including one which reserved to the United States government one-third of all the gold, silver, copper, and lead that might be mined. ${ }^{4}$ In 1807 , by a congressional act applying to Indiana Territory and all future territories to be created in the West, the principle of reserving mineral riches for special disposition was again recognized. All areas containing lead ore or saline deposits were reserved from the general land sale and leased for mining purposes. ${ }^{5}$

Exploitation of the area west of the Mississippi, however, proceeded slowly and no mineral lands were leased

3"Report of a Geological Exploration of Part of Iowa. Wisconsin, and Illinois, Made under Instructions from the Treasurer of the United States, in the Autumn of the Year 1839, by David Dale Owen, M.D., Principal Agent to explore the of the Year 1839, Dy United States," Executive Document, 26 Cong., 1 Sess., No. Mineral Lands of the United States, Executive Docutrent. This report was also 239 (June 6, 1840), 11. Cited hereafter as 1. W. 1 . Report. This 11, 1844), and will printed as Senate Document, 28 Con

be cited as $I$. W. I. Report, 1844 . James Whiteomb was a citizen of Indiana, a state senator, and governor of the state, 1843-1845. He served as Commissioner of the Land Office 1836-1841. Because Robert aided David in securing the appointment as State Geologist of Indiana, and Robert aided David in securing the another federal appointment for him, it is persumed that later (1847), secured another federal appointment Robert Dale Owen was a DemoRobert had a hand in the apyointment of 1839. 1836-1839, and a member of Concratic member of the Indianard W. Leopold, Robert Dale Owen, A Biography

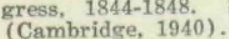

Cambridge, 1940). colos of all or part of colonization period whereby the erown to private persons. See United States Public the mineral wealth on land granted to private persons. C., 1844), 306

Land Commission, The Public Domain (Washington, D. C." ${ }^{5}$ United States Statutes at Large, II, 449 ; James F. Gallbreath, "Government Control of the Miners
No. $430(1916), 4$. 
until 1822 and it was not until 1826 that any extensive lead mining began. ${ }^{6}$ The richest ore fields were found in the neighborhood of Galena, Illinois; Dubuque, Iowa; and Mineral Point, Wisconsin. Here the mining of lead ore was the principal occupation of the settlers and in the 1820 's all of these communities but Dubuque, then still Indian territory, were bustling little boom towns. ${ }^{7}$

Until 1823 the supervision of the lead lands had been in the hands of the Land Office, but in that year the Ordnance Office of the War Department assumed control and an army officer was sent to the Northwest as "Superintendent of the Lead Mines." powered to lease mining land under the statute of 1807 . For a time he enforced the law without difficulty. Most of the mine operators were working small areas, and they supported the authority of the Ordnance officer because he protected them from the large operators who would rather have seen the land offered for sale. ${ }^{9}$

There were two problems involved in the administration of the reserved land. The task of executing the leases and collecting the rents was entrusted to the Ordnance officer; but the actual determination of areas containing lead ore was left in the hands of the surveyors employed by the Land Office. These men were expected to discover and define mineral lands at the same time that they were running lines for the rectangular survey. ${ }^{10}$ The land surveyors, of course, were not competent to perform a mineral survey and as a result ore bearing areas were

"Reports Relative to the Lead Mines and Salt Springs," Senate Document. 19 Cong., 1 Sess., No. 38 (1826), 10; George P. Merrill, The First One Hundred Years of American Geology (New Haven, 1926), 196; William J. Johnston, "Sketches of the History of Stephenson County, Iil.," illinois State Historical Library, Publication No. so (1923), 239-244; W Willard R. Jillson, "Early Mineral Exploration in the Mississippi Valley," Mlinois State Historical Library, Publication No. 31 (1924), 45-49; Benjamin J. Hibbard, A History of the Public Land Policies (New
York, 1924), 513.

TMoses Meeker, "Early History of the Lead Regions of Wisconsin," Wisconsin State Historical Society, Collection, VI (1872), 271-296; Joseph Schafer, The Wisconsin Lead Region (Wisconsin Domesday Book, General Studies, III), Madison, 1932, passim; James Shaw, "Geology of Jo Daviess County," A. H. Worthen, Economical Geology of Illinois (Springfield, 1882), III, 37-53; Benjamin F. Gue, History of Iowa (New York, 1903), 109-114; "Letter .. . . in Relation to Leases of Lead Mines Salt Springs," Senate Document, 19 Cong.; 1 Sess., No. 45 (Feb. 22, 1826), 16-19.

${ }^{8 " R e p o r t s}$ Relative to Lead Mines and Salt Springs," Senate Document, 19 Cong.,
Sess., No. 45 (1826) 16-19.

Document, 19 Cong., 1 Sess, (1826) 18 of Lead Mines and Salt Springs," Senate 10"'

Cong., 1 Sess., No. 38 (1826), 9. 
quite inaccurately designated. There was much confusion and misunderstanding as to just which land should be reserved for leasing. ${ }^{11}$ In spite of this potential cause for trouble the Ordnance officer experienced little difficulty in the supervision of the lead mines and rents were readily collected. So long as the residents of the region were interested only in lead land of sufficient richness to justify mining the inexactitude of the differentiation caused no trouble. ${ }^{12}$

For a time matters ran along with little friction. The Black Hawk Indian War of 1832 caused an exodus of miners and lead production was temporarily reduced. But Black Hawk and his warriors were soon defeated, and on September 21, 1832, the Sauk, Fox, and Winnebago Indians were forced to agree to a treaty whereby they ceded a large area in Iowa and lower Wisconsin to the government which was to be open for white settlement on and after June 1, 1833. The Indian land cession was the signal for a great influx of settlers looking for farm land. Colonel George Bomford, the chief of the Ordnance Office, could see trouble ahead. Farmers were going to insist that marginal lead land should be sold for agricultural use. The lead miners were going to ask that all land containing ore of any quality should be held for leasing. Further, large mine operators would have preferred buying up extensive tracts of land to leasing the much smaller units. So it was, then, that Colonel Bomford, in his annual report urged upon Congress the necessity of amending the law of 1807 to permit the sale of mineral land and the discontinuance of the leasing policy. ${ }^{13}$

The Colonel's apprehension of trouble was realized in 1835 when the miners of Illinois refused to pay the Superintendent of the Lead Mines the rent for their leases, claiming that the law did not provide for the method of rent collection that was being used, and also that it was unconstitutional for the United States government to

\footnotetext{
11"Report of the Ordnance Department," Senate Document, 22 Cong., 2 Sess., No. 2 (1832), 138-139.

127bid. (1833), 162.
} 
collect rent for any land within the boundaries of any state. The superintendent instituted suits to collect, hoping that a court decision would clarify the situation. Colonel Bomford, nevertheless, in a gloomy I-told-you-so report again recommended that the best way to settle all difficulties was to stop leasing and open all the reserved land to public sale. ${ }^{14}$

The situation in the Northwest was further complicated by three-way friction among the miners, farmers, and the local land office officials. In 1834, when the Mineral Point Land District agent began public sale, the Commissioner of the Land Office had ruled that any land could be sold if the purchaser would take an oath that there were no mineral ores in the tract he proposed to buy. In practice this proved to be very unsatisfactory because the agent had no means of being certain that the buyer was not making a false affirmation, since the only knowledge of just which sections contained lead ore came from the reports of the land surveyors. ${ }^{15}$ Consequently some of the land sold for farming actually contained lead ore. Numerous false oaths were given, too, and much ore-bearing land passed into the hands of the large mining operators, much to the indignation of the miners who had been paying rent to the government for years. ${ }^{16}$ It was charged that the local land agent was in collusion with those who were trying to defraud the government, but an investigation by the United States district attorney exonerated the agent and showed that he simply had no reliable information upon which to decide whether land should be sold or reserved. ${ }^{17}$

So involved had the situation become that the whole mining district seethed with dissatisfaction and unrest, and local officials were unable to work their way out of

\footnotetext{
14" Report of the Ordnance Department," Senate Document, 24 Cong., 1 Sess., No. 1 (1835), 235.

${ }^{15}$ "Report of the Secretary of the Treasury in Compliance with the Resolution the Senate ... in Relation to the Settlement of the Mining Country Senate Document, 25 Cong., 2 Sess. No, 411 (1835) the Mining Country . . . ," 16"Report of the Secretary of War, in Complianee-8.

Senate. R in Relation to the Sale War, in Compliance with a Resolution of the Cong., 2 Sess., No. 93 (1835), 4ff.

of Wiskonsin [sic] Mining Def the Treasury upon the Petition of the Inhabitants Document 26 [sie] Mining District, Praying for a Redress of Grievances," Senate 122.
} 
the muddle. The miners petitioned Congress for relief, and the House committee on public lands reported that the facts stated by the petitioners were "generally established," and that "the rights and interests of the United States, as well as of individual citizens, in the lead-mines of the government, have become greatly jeopardized."18

As a result, Congress took steps to remove one of the causes of the grievances. A resolution of the House of Representatives, passed February 6, $1839^{19}$ commanded the President

to cause to be prepared, and presented to the next Congress, at an early day, a plan for the sale of the public mineral lands, having reference as well to the amount of revenue to be derived from them, and their value as public property, as to the equitable claims of individuals upon them; and that he at the same time communicate to Congress information in the possession of the Treasury Department relative to their location, value, productiveness, and occupancy; and that he cause further information to be collected, and surveys to be made, as may be necessary for these purposes.

President Van Buren sent the resolution to the Secretary of the Treasury who referred it to Commissioner Whitcomb of the Land Office. ${ }^{20}$ Whitcomb found no information in his files except the surveyors' untrustworthy reports. In his perplexity he availed himself of the congressional permission to collect "further information." 21 Among those to whom the Commissioner turned for assistance in securing help in preparing such a plan asked for by Congress were the registers of the local Land Office districts. These were asked to consult the miners and to invite from them suggestions for the disposal of the government's mineral lands. ${ }^{22}$ But in the meantime, the precise location of mineral deposits in these western lands had to be determined or all was of no avail.

${ }^{18}$ Committee Reports, 26 Cong., 2 Sess., No. 1 (1839), $1,4$. soLevi Woodbury, Sec. of the Treas., to Martin Van Buren, President of the United States, June 4, 1840, I. W. I. Report, 2.

nJames Whitcomb to Levi Woodbury, June 3,1840, I. W. I. Report, 2.

${ }_{20} \mathrm{~A}$ mass meeting of miners was held at Dubuque Saturday, Sept 14, and again Sept. 21. A set of resolutions and a proposed bill to grant miners the equivalent of pre-emption rights were
(Dubuque), Sept. 28, 1839. 
GE OLO GICAL CHART

IOW A, WISCONSIN, AND

embracing the

ILLINOIS.

and probably

BYD.D.OWE

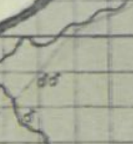

Iith by W Weber c Co Batianore

Ar colored stratum.

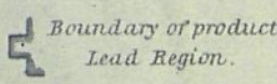

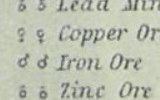

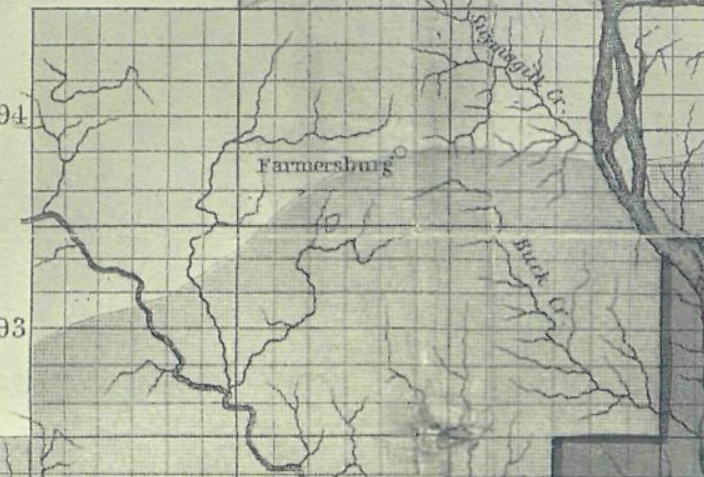

\section{\}$^{2}\left\{\begin{array}{l}w^{2} \\ x_{3}\end{array}\right.$}

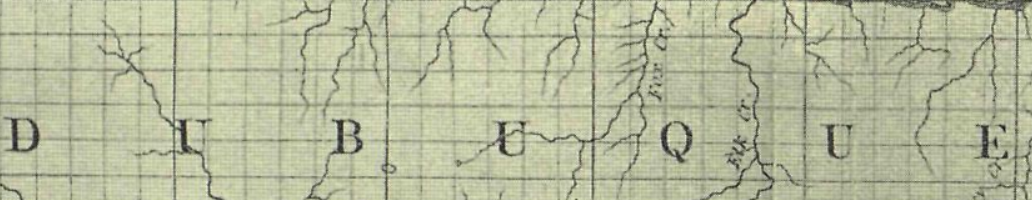

${ }^{80}\left\{\begin{array}{l}\text { D } \\ \text { I }\end{array}\right.$ \{.

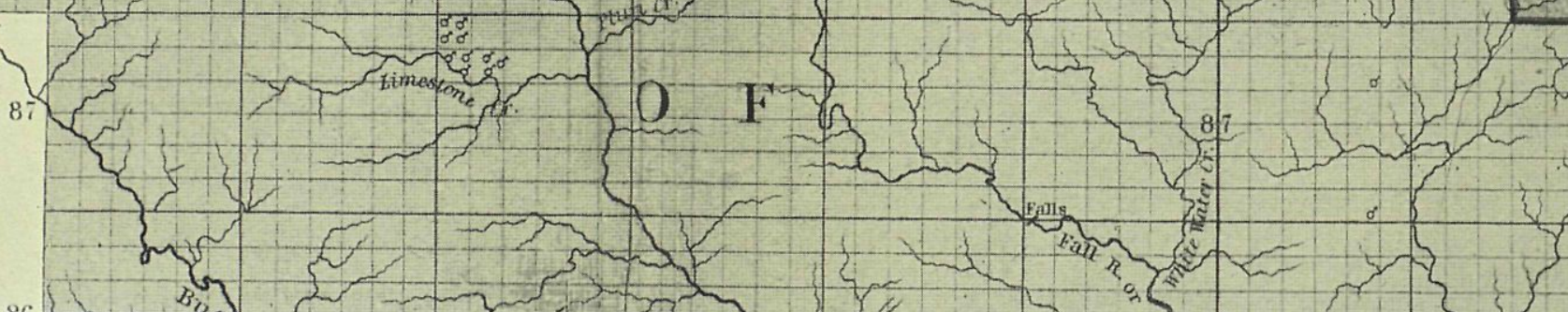

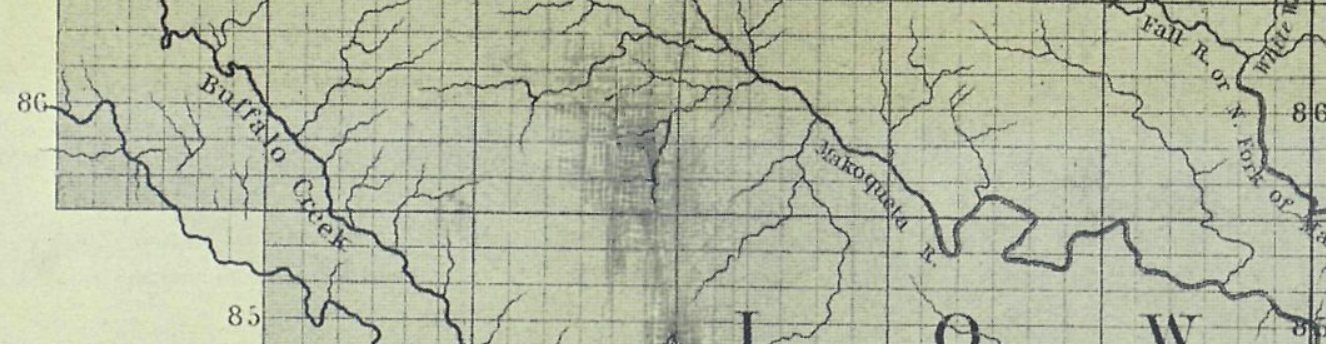

डैलsio.

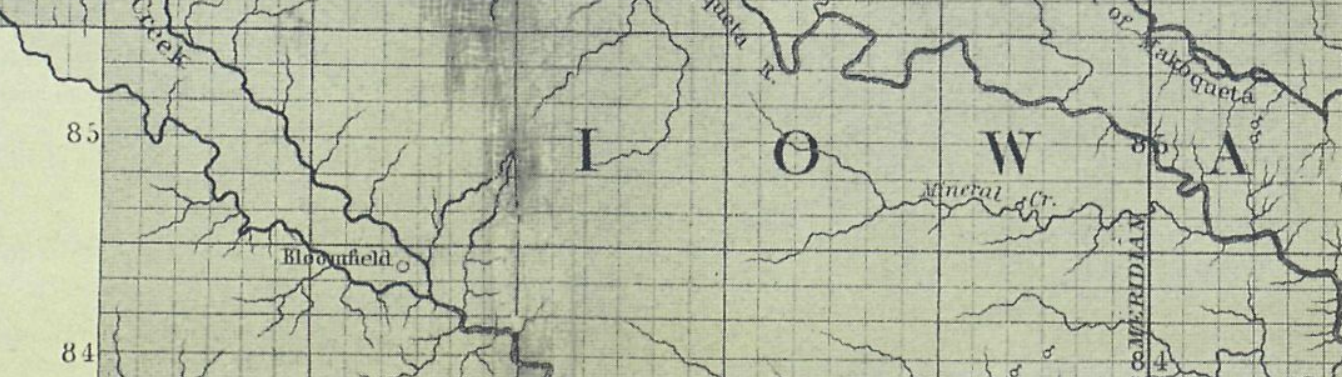
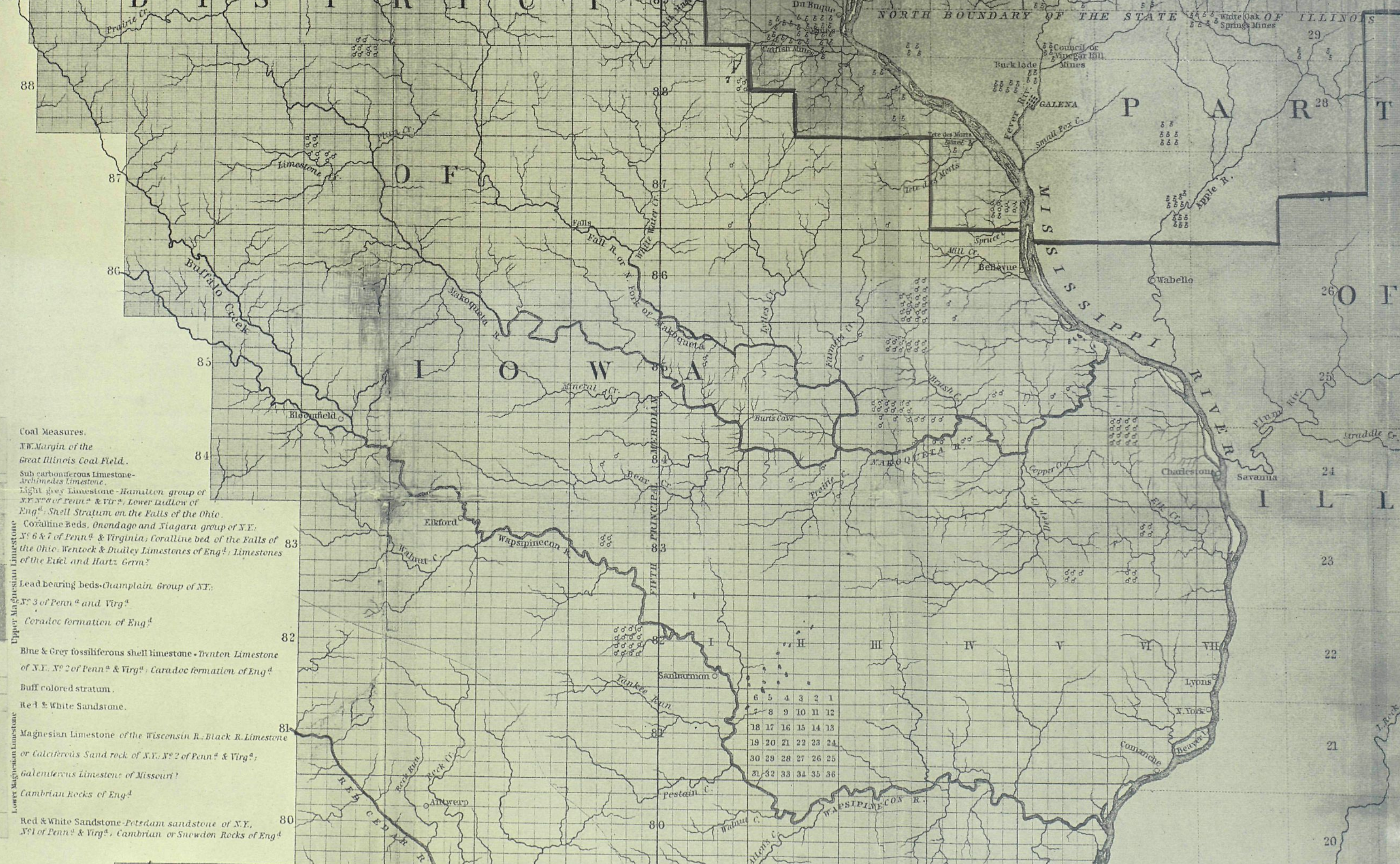

-

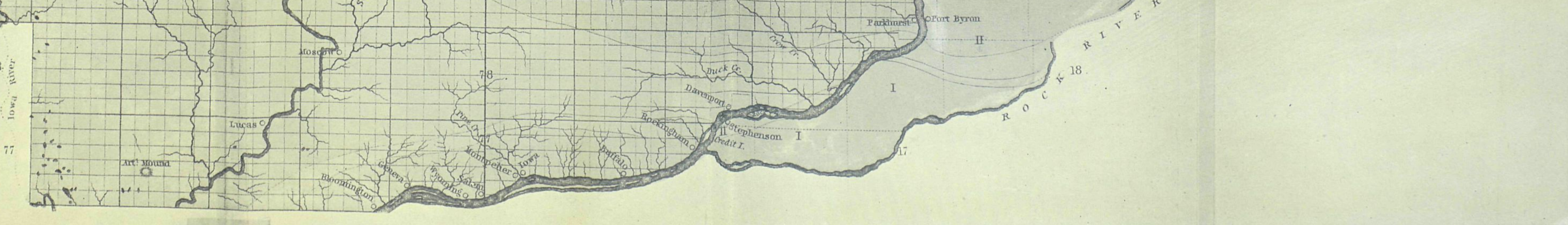


Thus it was that David Dale Owen was appointed "Principal Agent to Explore the Mineral Lands." The appointment reached him at his home in New Harmony on August 17, 1839, accompanied by instructions for the guidance of the geologist. These were quite detailed and explicit. The Hoosier scientist was to survey the Mineral Point, Galena, and Dubuque Land Districts and investigate "every description of mineral deposit calculated to impart so much value to the land as to justify the expense [of the survey], and which could be completed by winter." Owen was to hire agents and sub-agents, proceed to the south end of the Dubuque district and go north. Since it was desired that all lands not showing evidence of "lead, minerals, or salines, and not otherwise reserved, be brought into market at the earliest [time] practicable in the fall," he was to send in reports of the value and productiveness of the land, as soon as the examination of ten to fifteen townships was completed. He was to "take every opportunity to undeceive settlers" who might think he threatened their "supposed rights," because their cooperation would be helpful, and they could give much useful information. Because of the "delicate duties" and great trust imposed upon them, he was to select sub-agents and assistants of good moral character "not directly interested in the mineral lands." ${ }^{23}$

The youthful geologist pondered over these instructions. He was being asked to perform the well-nigh impossible! The territory to be surveyed comprised an area of 11,000 square miles. Barely two months remained before the onset of winter. ${ }^{24}$ The country to be surveyed was wild and sparsely settled, and travel and transportation of supplies would be difficult. ${ }^{25}$ Yet, a careful weighing of all factors involved convinced Owen that the task could be done. Systematic organization and an adequate and well-trained working force would ensure the completion of

9ames Whiteomb to D. D. Owen, July 31, 1839, Miscellaneous Correspondence, Division of Mails and Files, General Land Office, Department of the Interior, Washington, D. C., Shelf No. 76 (Cited hereafter as L. O. Mise. Corr.)

${ }^{29} \mathrm{D}$. D. Owen to James Whitcomb, Rockingham, Iowa, September 10, 1830, Register of Letters Received, Division of Mails and Files, General Land Office, Department of Interior, Washington, D. C., Shelf No. 91 (Cited hereafter as L. O. Reg. Let. Reed.)

${ }^{2}$ I. W. I. Report, 1844. 
the survey in the time allowed, but at an expenditure greater than the Land Office anticipated. ${ }^{26}$ Owen interpreted his instructions to mean that results were desired regardless of expense. The Secretary of the Treasury did question the estimate that Owen submitted to Whitcomb, ${ }^{27}$ but by the time that any steps could be taken to halt Owen's plans, the geologist was in the field and had completed part of the work. The Commissioner, harassed by the problems of the mineral lands, gave Owen loyal support, and pointed out that if the survey was stopped, the money already spent would be wasted. ${ }^{28}$

Working against time, Owen prepared to take the field. A force of over a hundred was needed and twenty New Harmony men volunteered. ${ }^{29}$ With this group as a nucleus for his corps, Owen went to St. Louis to complete his preparations. He hired more men, and bought provisions, instruments, and equipment, paying for them with his personal note for $\$ 3,000 .^{30}$ By dint of much hard work and careful planning the entire corps of men was assembled and ready for work in the field in just one month from the day that Owen had received his instructions. ${ }^{31}$

Then began a whirlwind survey of 11,000 square miles of territory. Owen's raw and largely untrained force had been given a short course in the principles of geology and instructed in the use of simple chemical tests for mineral identification. Even on the steamboat which carried the expedition to Rockingham, the geologist held classes for his men. In the cabin he displayed suites of rocks, charts, and maps, and drilled them in the fundamentals of field surveying. ${ }^{32}$ Owen had one trained geologist on his staff,

$26 \mathrm{fbid.;}$ The estimated cost was about $\$ 10,000$ but Owen spent $\$ 34,000$. See James Whitcomb to Levi Woodbury, Sept. 17, 1839, L. O. Misc. Corr., Shelf No. 76 and D. D. Owen to James Whitcomb, New Harmony, Apr. 3, 1840, L. O. Reg. Let. Reed., Shelf No. 91 .

20. D. D. Owen to James Whiteomb, New Harmony, Aug. 27, 1839, L. O. Reg. Let. Recd., Shelf No. 91.

28 James Whitcomb to Levi Woodbury, Sept. 11, 17, 18, 1839, L. O. Misc. Corr., Shelf No. 76.

20I. W. I. Report, 1844, 13; Wm. Amphlett to Wm. Maclure, New Harmony, Sept. 26, 1839, Maclure Papers. (In the Workingmen's Institute Library, New Harmony, Indiana).

30I. W. I. Report, 1844, 13; D. D. Owen to James Whitcomb, [St. Louis ?], Sept. 5, 1839, L. O. Reg. Let. Recd., Shelf No. 91.

sil. W. I. Report, 1844, 13: D. D. Owen to James Whitcomb, [Rockingham, Iowa?], Sept. 18, 1839, L. O. Reg. Let. Recd., Shelf No. 91.

3.J. Schneck and Richard Owen, The History of New Harmony, Ind. (Evansville, 1890$), 8$. 
Dr. John Locke of Cincinnati, who was to make a report on the dip of the rock formations. Locke also was to make some experimental magnetic readings with a specially sensitive compass which he had designed. ${ }^{33}$

When the whole contingent arrived at Rock River, Owen divided his force into twenty-four working corps, each in charge of a sub-agent. They were sent to stations at the township lines along the boundary between the Dubuque and Burlington land districts, on the west side of the Mississippi. Owen arranged for each corps to report to him at fixed times and places. In order to keep these appointments, he traveled back and forth across the region eleven times. ${ }^{34}$ He calculated that it would be necessary for each corps to examine thirty quartersections of land, or the survey would not be completed on time. ${ }^{35}$ Constant supervision was necessary to maintain this schedule. Every few days Owen reported to the Land Office the amount of territory surveyed and sent maps indicating the townships in which mineral deposits were found. The abstracts of these reports give brief glimpses of the rapid progress that was made. September 25, six days after work was begun, ten townships (360 square miles), had been examined. On October 2, the survey had advanced north of the Wapsipinicon River, and a total of forty townships had been completed. Then the corps proceeded to the Yellow River, then over into Wisconsin to Prairie du Chien and Mineral Point and back to Rock River. Always the detached corps moved northward. ${ }^{36}$ It was difficult to maintain the exacting schedule demanded by the exigencies of a race against time. Rain and consequent dampness, combined with the hardships of camp life, caused sickness among the men. Several became so ill that they were relieved from duty, and on October 2 one man died of "congestive fever." The first report, in the Burlington Gazette, was that Doctor David

\footnotetext{
${ }^{33}$ James Whiteomb to D. D. Owen, Sept. 10, 1839, L. O. Mise. Corr., Shelf No. 76 I. W. I. Report, 1844, 65, 163; Iovea Sun (Davenport), Nov. 6, 1839, quoting Iowa News, n. d.

4D. D. Owen to James Whitcomb, [Rockingham, Iowa?], Sept. 18, 1839, L. O.

Reg. Let. Reed., Shelf No. 91; I. W. I. Report, 1844, 13.

s5I. W. I. Report, 1844, 13.

5eD. D. Owen to James Whitcomb, n. p., Sept. 25, Oct. 2, Oct. 5, 1839, L. O. Reg. Let. Recd., Shelf No. 91; Iowa News, Oct. 5, 1839.
} 
D. Owen himself had died. Though this was promptly denied by the Iowa Sun at Davenport, the false story gained great currency before overtaken by its correction, later in the fall. ${ }^{37}$

Commissioner Whitcomb instructed Owen to secure the co-operation of the people of the territory and assure them that the government would look after their interest. Consequently Owen was as conciliatory as possible, and sought to secure the support of the newspaper editors for himself and the government. The papers of Dubuque and Davenport were given full information about the progress of the survey, and the editor of the Iowa Sun at Davenport spent several hours in the field with Owen and Locke. The Sun also published extracts from Owen's instructions in which the settlers were asked to co-operate with Owen. Everywhere the geologist was warmly received and he won the confidence of farmers and miners alike. He listened to everyone, and his patient explanation of the purpose of the survey did much to allay the friction between the Land Office and the miners and the farmers. The latter were fearful that the land to be opened to purchase after Owen's reconnaissance might be placed on the market in the midst of winter when it would be difficult for the prospective settlers to attend the sale. Owen recognized the justice of the complaint, and urged the Commissioner to await until spring before opening new areas. Whitcomb was pleased with Owen's handling of the situation and readily granted the request..$^{38}$

When the geologist visited Dubuque, John Daugherty and other lead mine operators enthusiastically displayed their mines and permitted him to examine them thoroughly. Owen would have been wined and dined by the leading citizens but for the fact that he had to hurry away to keep an appointment with a sub-corps. The inhabitants of

3rD, D. Owen to James Whiteomb, n. p., Oct. 2, 1839, L. O. Reg. Let. Reed., Shelf No. 91. The man's name was Soper, and he was replaced by an engineer, Owen P. Owen. The coincidence of names helped to give rise to the rumor. Burlington Gazette, Iova Sun, Niles Register, Oct. 26, 1839, repeated the story, and Burlington Gazette, Iono Sun, Nites Register, Oct. 26, 18s9, crat. Nov. 22, 1839 . When the truth was known a retraction was just as widely circulated. See Niles Register. Nov. 2, 1839, and Indiana Demoerat, Nov. $26,1839$.

38D. D. Owen to James Whitcomb, n. p., Sept. 25, 1839, L. O. Reg. Let. Recd., Shelf No. 91; James Whiteomb to D. D. Öwen, Oct. 23, 1839, L. O. Misc. Corr., Shelf No. 76; Iova Sun, Sept. 25, 1839. 
Iowa felt that Owen's survey, when its results were published, would spread the fame of the territory's mineral wealth and fertile soil. ${ }^{39}$

Owen's vigorous prosecution of the survey resulted in complete success. On November 14 the last township was examined. On the very day that the work was completed "a severe snowstorm occurred, a gale blew up from the northwest, the thermometer fell to twelve or fourteen degrees below zero, and the expedition could not have continued its operations in the field a single day longer." 40 During the following week the corps, traveling down the Mississippi in steamboats, was disbanded at Stephenson, Illinois. The impossible had been done!

During the winter of 1839-40 David Dale Owen prepared maps of the area which he had examined. On them were indicated the exact location of mineral veins and the sites of actual mining operations. These maps provided the Land Office with a permanent and authentic guide whereby the Commissioner would be able to decide just which areas should be offered for outright purchase, and the first based upon the maps took place in the Dubuque Land District in the spring of $1840 .{ }^{41}$

-Walter B. Hendrickson is Assistant Professor of History in Mac Murray College, Jacksonville, Illinois. His full length biography of David Dale Owen is to be published soon by the Indiana Historical Commission as a volume in its Historical Collections.

soIndiana Demoerat. Nov, 22, 1839, quoting Iowa Neros, n. d.

toI. W. I. Report, $1844,14$.

11D. D. Owen to James Whitcomb, New Harmony, Feb. 9, 1840, L. O. Reg. Let. Reed., Shelf No. 91. It was not, however, until 1846 that Congress abandoned the policy of leasing the lead ore fields, and threw them open to sale at a minimum price of five dollars an acre. 
Copyright of Annals of Iowa is the property of State of Iowa, by \& through the State Historical Society of Iowa and its content may not be copied or emailed to multiple sites or posted to a listserv without the copyright holder's express written permission. However, users may print, download, or email articles for individual use. 